\title{
Rage Slaves: \\ The Commodification of Affect in The Five Lesbian Brothers' The Secretaries ${ }^{1}$
}

\section{Sara Warner}

\author{
It seems that my mouth is full of birds which I crunch \\ between my teeth. Their feathers, their blood and broken \\ bones are choking me. I carry on my work as a secretary. \\ - Caryl Churchill and Davin Lan, A Mouthful of Birds
}

"I guess the question I have to ask myself is, 'How did a decent girl like me get involved with a cult of murderous secretaries?" In this direct address to the audience in Scene One of the Five Lesbian Brothers' The Secretaries, protagonist Patty Johnson entices spectators with the promise of a lurid tale of a good girl gone bad. Though we begin the play perplexed by how it is that pretty Patty, who comes from a good family, has an advanced degree in secretarial sciences, and speaks six languages, could turn into a chainsaw wielding serial killer, we leave this maenadic masterpiece pondering the more pressing problem of how could she not. In The Secretaries, Peaches Martin, Ashley Elizabeth Fratangelo, and Dawn Midnight, three administrative assistants who work at the Cooney Lumber Mill in Big Bone, Oregon, welcome the addition of a new employee, Patty, into their secretarial pool. The department manager is Susan Curtis, a narcissistic, male-identified dominatrix who does the dirty work for the big boss, a chauvinist pig named Mr. Kembunkscher, a man so omnipotent and omniscient that his voice on the intercom sends the secretaries into a frenzy. These warped word processors, Patty soon learns, put the secret in secretarial. The office pool is really a gynocentric grist mill, a catty cabal that serves primarily to facilitate the ritual sacrifice of a lumberjack once a month, on the day when the secretaries begin their shared menstrual cycle. Resistance proves futile for poor Patty. In fact, she doesn't simply succumb to the secretaries; she becomes their new leader. Through outrageous antics and cunning linguistic moves, such as rhyming "secretarial" with "burial" in the opening "song," the play, in Peggy Phelan's estimation, "winks at the audience, and makes them complicit

\footnotetext{
Sara Warner is assistant professor of Theatre at Cornell University, where she also teaches in the LBG Program and Feminist, Gender, and Sexuality Studies Program. She has published in Feminist Studies, Theatre Journal, and Dialectical Anthropology. Sara has served as President of the Women and Theatre Program and Drama Division delegate of the Modern Language Association. She is currently secretary of ATHE and a member of the Board of Directors of the Center for Lesbian and Gay Studies at the City University of New York.
} 
in the play's seduction: We know that secretaries are not man-hating lesbians . . . but let's just suppose they are."2

Because the play culminates in a neo-Bacchic rite, in the spectacular slaughter of a male interloper into the clandestine world of women, theatre audiences often miss the more subtle forms of cruelty and violence the females inflict upon each other. The Secretaries examines the ways in which women serve as the primary agents of their own oppression through the internalization of misogyny and slavish adherence to highly ritualized self destructive behavior that masquerades as self improvement. According to Phelan, "the secretaries go over the top to show us the apparent bottomlessness of routine cultural misogyny, a hatred that thrives not only on violence against women ... but that, perhaps more darkly, also sustains violence between women." She reads the play as an exploration of women's repressed anger at sexism, one that addresses the question bell hooks asks in "Moving into and Beyond Feminism": "what do we do as women with our rage?"4 Routine cultural misogyny, however, does not adequately address the source or intensity of anger and violence in the play. In order to find the root of the secretaries' rage, we must consider the given circumstances of the script, and in particular the direct relationship between the secretaries' violence and their occupation. The Secretaries probes the homosocial, homicidal horror fest that is the office pool. In order to fully appreciate this play, we must begin with an analysis of the secretaries qua secretaries, that is, as female laborers in a service economy. I argue here that the problem The Secretaries so pointedly poses is what do we do as women workers with our rage.

This play contradicts the commonly held assumption that the ability to work in the public sphere liberates women from economic dependence upon males, arguing instead that it doubly indentures them. Like the protagonists in this production, the majority of real women work in the service economy, a sector whose recent rapid growth marks the transition from industrial to informational capitalism. Economic postmodernization, the term commonly used to describe this new phase of capitalism, is accompanied by a corresponding shift in labor practices, from a system based upon physical labor to one rooted in what Arlie Hochschild terms "emotional labor." Emotional labor is marked most fully by what has traditionally been designated as “women's work": caring, nurturing, and maternal activities. In preindustrial and industrial societies, emotional labor plays a minor but important part of the economic fabric of society, primarily in the domestic sphere. In informational societies, the service sector dominates, and emotional work becomes the apex of laboring forms. Service economies are based upon the buying and selling of emotions (as in "service with a smile"), which, according to Hochschild, inevitably results in the commercialization of human feelings. Given that women are the primary laborers in the service economy, and given that they continue to perform the majority of emotional labor in the domestic sphere, they are subject 
to greater and more extensive forms of the commodification of affect.

The Secretaries provides an interesting vantage point from which to ponder the relationships among emotions, gender, and labor in the period of economic postmodernization, one that exposes some surprising and hitherto unexamined aspects of an informational labor society. How, for example, does it happen that so-called "women's work," which has historically been underpaid and undervalued, becomes the pinnacle of capitalist production? What role has feminism played in effecting this transition? What are the unexpected and unintended social and political effects of this monumental shift? Taking Hochschild's conclusion as my starting point, I offer here a reading of The Secretaries as a parable of the commodification of emotions in the period of economic postmodernization, or what I am calling the age of affective reproducibility. This brilliant and shamefully neglected play exposes two seemingly unrelated but completely imbricated consequences of economic postmodernization and the rise of affective labor. The first is the creation of what I term the rage slave, the alienated emotional laborer in a service economy, and the second is the engendering of a queer sociality that detaches capitalism from heteronormativity.

A rage slave is to informational capitalism what a wage slave is to industrial capitalism and what a chattel slave is to plantation capitalism. A chattel slave is the property of a master. He is denied personal freedom and compelled to perform unpaid labor under the threat of death. A wage slave is a free person, but he remains bound in so far as he must sell his labor, or labor power, for wages under the threat of starvation and poverty. ${ }^{6}$ A rage slave is a wage slave in a service economy, someone who sells both her labor power and her emotions under the same compulsions. ${ }^{7} \mathrm{~A}$ detailed reading of The Secretaries in and through affect theory enables us to see the ways in which economic postmodernization creates and is contingent upon rage slave labor.

The Secretaries suggests that economic postmodernization's dependence upon rage slave labor precipitates the waning of capitalism's heteronormative imperative, as the very forces that made industrialization possible, namely the nuclear family and sexual reproduction, are precisely what pose the greatest threat to an affective labor force. Informational capitalism engenders a new structure of feeling, to borrow a term from Raymond Williams, in which lesbians, at least from the perspective of industry, are the ideal rage slaves. ${ }^{8}$ I am interested here in The Five Lesbian Brothers' enactment of what is problematic about how affect is gendered and commodified and how this commodification is contingent upon a queer sociality.

\section{Affective Labor}

The transition from industrial capitalism (based on physical labor) to informational capitalism (rooted in emotional labor) began in the 1970s and coincides, in the United States and Europe, with various feminist movements, 
the proliferation of women in the marketplace, and the creation of a pink collar workforce. ${ }^{9}$ Emotional or affective labor is an example of what Michael Hardt calls immaterial labor, labor that involves the body but produces no durable or material goods. While manufacturing and production continue, especially in developing nations, immaterial labor is now "directly productive of capital" and represents "the very pinnacle of the hierarchy of laboring forms." Immaterial labor is characterized by knowledge, information, communication, and affect and includes everything from education, healthcare, and entertainment to finance, advertising, and transportation. These services are intangible but have a corporeal dimension; they involve the production of "a feeling of ease, well-being, satisfaction, excitement, passion - even a sense of connectedness or community." 10

Hardt identifies affective labor as the most important form of immaterial labor in part because of its subversive potential, its ability to generate "an autonomous circuit for the constitutions of subjectivity, alternative to the processes of capitalist valorization." 11 While he credits feminism with ushering in the "affective turn" in critical discourse, he downplays the wealth of scholarship on the relationship among gender, affective labor, and socio-economic oppression that feminist theory has produced. ${ }^{12}$ Affective labor may be rooted in women's work and may even represent a revalorization of embodiment, sentiments, and domesticity, but we cannot ignore the fact that the most highly valued and lucrative jobs in the service economy are (still) typically performed by men. Nor can we ignore the fact that affective labor often results in the double exploitation of workers, in the commodification of their bodies and emotions.

One negative consequence of the rise of emotional labor is the false consciousness that a sense of belonging can be achieved through purchase, through affective consumption. Businesses and governments seem to work in tandem to produce and promote unrest and unease in an effort to spur citizen-consumers to buy into an identity or collectivity. Anxiety is manufactured and terror exacerbated by fear mongers in order to sell more services or a bogus bill of goods, such as the Patriot Act, which simultaneously lowers the public's expectations of privacy rights and increases the profits of companies in the lucrative surveillance and reporting industries. ${ }^{13}$ Retail therapy is promoted as a form of political resistance. Hence George W. Bush's and Rudy Giuliani's calls to Americans to demonstrate their fearlessness and courage by going shopping and catching a Broadway show in the wake of September 11. Hardt drastically downplays such negative effects, in part because he makes little or no distinction between the various forms and functions of affective labor. Even his choice of terminology-the exclusive use of "affect" rather than "emotion"-reveals a desire to transcend the realm of the feminine, the subjective, the personal, and the abject that have historically been associated with feelings.

The use of "affect" rather than "emotion" was popularized in the late nineteenth 
century by psychoanalysts as a way to differentiate between feelings experienced by analysands and those observed by analysts. Many postmodern theorists, including Hardt, prefer affect to emotion because it offers a way to talk about feelings after the death of the subject, in a nonessentialist, nonidentitarian way. Affect also thwarts that long standing binary opposition between thought and feeling. In Multitude, the follow-up to Empire, Hardt and his coauthor Antonio Negri write, "Unlike emotions, which are mental phenomena, affects refer equally to body and mind. In fact, affects, such as joy and sadness, reveal the present state of life in the entire organism, expressing a certain state of the body along with a certain mode of thinking. ${ }^{.14}$ Many feminist theorists, myself included, acknowledge poststructuralist conceptions of subjectivity and the desire to disrupt the duality between reason and emotion, but continue to use the term emotion (alone or in conjunction with affect and/or feeling) in part to foreground the role of the women's movement in ushering in the current affective turn and to resist the critical violence of supersession. ${ }^{15}$ The idea that affect entails the denigration or displacement of emotion parallels performance theorists' supersession of theatre and queer theorists' supersession of lesbian and gay.

Utopian possibilities of affective labor notwithstanding, the reality is that the top three occupations for women fall under this category: secretaries ( $96 \%$ female), nurses (90\% female), and teachers ( $80 \%$ female).${ }^{16}$ These three professions account for $31 \%$ of all women in the U.S. labor force. Secretarial/clerical work is the single largest job category for the American working girl. More than one-fourth of all women work in administrative support. ${ }^{17}$ Like teachers and nurses, secretaries control the flow of information; they possess knowledge, but rarely in ways that benefit their status. Sanitation workers and bus drivers, two male dominated forms of immaterial labor, typically earn more money and garner better benefits. This gender disparity is even more pronounced when we consider the global labor market. As Gayatri Spivak notes, "It is a well-known fact that the worst victims of the recent exacerbation of the international division of labor are women. They are the true surplus army of labor in the current conjecture. In their case, patriarchal social relations contribute to their production as the new focus of super-exploitation." 18 Yes, patriarchy is to blame, but the question The Secretaries prompts us to ask is to what extent have women, and in particular feminists, contributed to this surplus army of super exploited female laborers?

Advocates of women's rights often operate under the erroneous assumption that there is a direct connection among employment, emotions, and emancipation. Both first and second wave feminists believed that the source of women's anger, frustration, and unhappiness was their forced economic dependence upon men. They fought for greater access to the public sphere and the ability to work for wages. Gainfully employed women, they reasoned, would no longer have cause to be disgruntled. This is the argument Virginia Woolf puts forth in A Room of One's Own. 
On the eve of women's suffrage, Woolf learned a distant aunt had died, leaving her a substantial yearly sum. "Of the two-the vote and the money, the money seemed infinitely more important." ${ }^{19}$ Financial independence, she reasoned, would not only free women from male domination, it would unfetter them from negative affects. Only then could women flower into full human beings and become great artists.

Woolf believed anything written "in the red light of emotion and not in the white light of truth" was an inferior work, and she placed A Room of One's Own in this category. Woolf not only wrote this treatise in anger, she wrote it about anger. "Anger" and "angry" appear thirty-nine times in the span of just over one hundred pages, and "rage" four times. She admits in her diary that she wrote A Room of One's Own "with ardour and conviction," and that as a result she "shall be attacked for a feminist and hinted at for a sapphist." ${ }^{20}$ Woolf would no doubt be surprised to learn that greater economic opportunity has not ameliorated women's anger, but on the contrary has exacerbated it. Rather than unfettering women from emotions, work (especially service work) binds them ever tighter to an even more restrictive affective register culminating, as we shall see, in rage slavery.

Second wave feminists enjoyed both the vote and the right to work, but remained second class citizens. Many believed, however, that this would be abated by eradicating discrimination in the workplace, shattering the glass ceiling, mandating equal pay for equal work, and having men share in chores and child rearing. As feminism gave way to feminisms and a greater diversity of voices weighed in on the issue of women and work, the notion that an occupation would lead to liberation was revealed as a fantasy of the white middle-class. ${ }^{21}$ As bell hooks notes, the idea that "women would be liberated if they worked" "was absurd to African Americans, who only had to stop and think, "GGee, every black woman I've ever known has worked (outside the home), but this hasn't necessarily meant liberation." ${ }_{22}$

It is not economic dependence so much as the exploitation of emotional labor (first at home and then in the marketplace) that is the problem. In his 1869 tract The Subjection of Women, economist John Stuart Mill identified emotional bondage and affective control as the foundation of women's oppression. "Men do not want solely the obedience of women," he notes, "they want their sentiments." ${ }^{23}$ Sentiment alone separates a wife from an indentured servant. "All men desire to have, in the woman most nearly connected with them not a forced slave but a willing one, not a slave merely, but a favourite." Masters maintain control of their slaves through fear, explains Mill, but fear alone will produce only obedience, not love, dedication, or devotion. These feelings must be given, not coerced. To ensure the voluntary sentimental servitude of women, men "put everything in practice to enslave their minds." From the time of their birth, the fairer sex is taught that "meekness, submissiveness, and resignation of all individual will into the hands of a man" are the attributes of sexual attractiveness. Women are made to believe it is their duty 
"to live for others; to make complete abnegation of themselves, and to have no life but in their affections." Even their emotional life is restricted, notes Mill, for "by their affections are meant the only ones they are allowed to have," namely those which "constitute an additional and indefensible tie between them and a man."

Mill exposed the ways in which women are reared to be emotional actresses of an established repertoire and men their directors, producers, and stage managers in the drama of domesticity. What the Victorians called "the nature of woman," he wrote, is not natural at all, but "an eminently artificial thing, the result of forced repression in some directions, unnatural simulation in others." A utilitarian, Mill believed that human beings could flourish only with the cultivation of feelings. ${ }^{24}$ The cultivation of feelings could lead to greater individual freedom, or it could be used in the opposition of liberty, as in the conditioning of women and servants to desire a subordinate social status. The shift in the terrain of women's labor, from the home to the marketplace, has resulted in an equally "eminently artificial thing," the service worker cum rage slave. She is in many ways the ideal Victorian woman, except that her emotional labors are performed in public rather than in private. The secretary is the paradigmatic example of this. She is the wife and mother of the capitalist machine, not a forced slave but a willing one, a paid one. Rigorously schooled in the art of affective manipulation, her feelings are cultivated to serve others and make her boss(es) feel like top brass.

Mill offers an interesting corrective to Marx, who, like Weber, focused his attention primarily on physical labor. ${ }^{25}$ Written two years after the first volume of Capital, in which Marx details the exploitation and alienation of labor in commodity capitalism, Mill's theory enables us to see the ways in which the economy is dependent upon the gendering and commodification of affect. He recognized that the effort individuals exert in learning when to suppress or stimulate certain feelings and the work of performing in social situations is part of the economic structure of society.

Emotional labor, notes Hochschild, makes human relationships possible. In a private or domestic context, it has what Marx called use-value, the utility of a thing or commodity. Use-value refers to the qualitative aspect of value, the concrete way in which an object or service meets a human need. While both sexes participate in this exchange in the domestic sphere, historically emotion management has been used by women as one of the offerings, along with sex, that they trade for economic support. Emotional labor traded in the public sphere has exchange value. Roughly equivalent to its price, emotional labor's exchange value reflects what it can be traded for on the market, its quantitative rather than qualitative value. Examples of the exchange value of emotions include the trust a flight attendant conveys, the sense of luxury a maid at a two-star hotel provides, and the feelings of comfort, convenience, and security a secretary makes possible by handling the "small" details such as scheduling appointments, typing reports, making travel arrangements, and 
organizing business lunches.

The service economy is built upon the exchange value of emotional labor. As emotions that were once private and guided by personal discretion go public, they are dictated by employers and monitored by supervisors with the goal of maximizing profits. The commodification of human feeling happens when companies create policies and practices designed to induce, retard, or prohibit specific emotions from its employees. This occurs, according to Hochschild, when "the emotional style of offering the service becomes part of the service itself." ${ }^{26}$ In the same way an assembly line worker becomes alienated from his or her body in a factory, an emotional laborer becomes alienated from his or her feelings in the service economy.

Hochschild was one of the first feminist theorists to demonstrate the ways in which human feelings, and in particular women's emotions, are commodified. In The Managed Heart, she turns to acting theory, adopting Konstantin Stanislavski's notion of habitual or mechanical acting, the dramatization of an emotion without actually feeling it, to explain what she calls surface acting, the type of emotional labor that requires an employee to maintain an outward appearance of an expected disposition while keeping her personal feelings hidden. ${ }^{27}$ Flight attendants are a great example. Their primary role is to ensure fliers' safety, but they are trained to act as if passengers' comfort were the top priority, hence the plastered on smile and solicitation of suggestions on how they can better serve you. This is the opposite, for Hochschild, of deep acting, which requires an employee to make a sincere effort to experience the emotions prescribed by a particular occupation, like the secretaries in the play that we will return to in just a moment. Deep acting is analogous to the Stanislavski System, which involves an actor actually experiencing the emotion she is performing. In An Actor Prepares, Stanislavski explains the difference between surface and deep acting as the distinction "between the two words seem and $b e .{ }^{228}$

Hochschild employs the distinction between seeming and being to explore the differences between a worker who feigns an emotion she was hired to convey and one who actually feels those sentiments (by "buying in" to the company philosophy). ${ }^{29}$ I term a rage slave the "deep" actor who has lost the ability to distinguish between seeming and being, feigning and feeling, one whose emotions are so thoroughly commodified that even her anger at the ways her emotions are induced, trained, purged, and otherwise exploited for capital gain is co-opted. The rage slave is a contingent foundation of economic postmodernization, and the ideal rage slave in this age of affective reproducibility is a lesbian.

\section{The Secretaries}

The Secretaries (1993) is the third full-length play collectively authored and staged by the Five Lesbian Brothers: Moe Angelos (Dawn Midnight/Buzz Benikee), 
Babs Davy (Ashley Elizabeth Fratangelo), Dominique Dibbell (Patty Johnson), Peg Healey (Susan Curtis), and Lisa Kron (Peaches). The Brothers developed the play at the WOW Café in the East Village, a site that has served as an incubator for the production of progressive lesbian communities and radical artistic experimentation for over twenty-five years. ${ }^{30}$ The Brothers, Phelan notes, have a reputation for "joining unconventional sexual desires with the creation of new theatre," providing a welcome alternative to mainstream feminism. ${ }^{31}$ Even their name suggests a parodic distancing from the second-wave dictate that "sisterhood is powerful." While antisex feminists were giving tours of Times Square porn shops, Jill Dolan reminds us, and Andrea Dworkin was preaching heterosexual intercourse as a form of rape, "the Brothers stormed the stage at WOW with outlandish enactments of the pleasure of penetration, of nonmonogamy, of the zany pleasures of a revolving door of sexual partners for whom no desire was off the map politically or physically."

According to The Five Lesbian Brothers, their raison d'être "is to explore such dark themes as homophobia and sexism with devastating humor and the occasional musical number." ${ }^{33}$ Brother Dibbell explains the collective's political aesthetic:

Lesbian feminism of the 1970 s and the 1980s had placed a heavy emphasis on 'positive images of lesbians.' But by the late eighties the emphasis had become a mandate. No good art can come of a mandate, so we incorrigibly did the opposite of what we were told: we instinctively returned to the image of the lesbian as pervert. ${ }^{34}$

Brother Kron adds, "We are equitable in our parody, skewering homosexuals and feminism with the same vigor we apply to mainstream culture." ${ }^{35}$ According to Alisa Solomon, "The genius of their work is that the Brothers don't use comedy to make a feminist, anti-homophobic point go down easy. The comedy is the point — and so is the anxiety and terror." ${ }^{\prime 36}$

Dolan considers the Brothers' work avant-garde in part for producing “outrageous, unheard of possibilities for lesbian desire, long before 'queer' entered the lexicon as an identity or a sexual practice." ${ }^{37}$ Actually, the group staged their first show, Voyage to Lesbos, in what is known as the "year of the queer," $1990 .{ }^{38}$ While queer goes a long way toward describing the Brothers nonnormative strivings, they are not, as both their name and the title of their first show attest, ready to trade in their lesbian identification for the moniker queer. The Brothers urge us to ask why we feel we must choose either lesbian or queer when women can - and should - demand both/and. The more pleasure, the better.

The Secretaries marked a turning point for the collective. Unlike their previous work, which was "loosely structured, fantastically plotted with no regard for cause and effect or the niceties of plot or character," The Secretaries is in many 
ways a conventional, well made play. ${ }^{39}$ This formula proved to be a recipe for success. Just as Suzan-Lori Parks's least experimental play, Topdog/Underdog, has become the most highly acclaimed and decorated work in her oeuvre, so too have the Brothers been rewarded for embracing formal structures and a coherent narrative. The Secretaries garnered the Brothers their first New York Times theatre review and a Special Citation OBIE Award. After a successful run at WOW, the play moved down the street to the New York Theatre Workshop (NYTW), an offBroadway venue known for staging politically engaged work by queer luminaries such as, Jonathan Larson, Doug Wright, and Tony Kushner. It ran for forty-five performances in the fall of $1994 .^{40}$

New York Times critic Ben Brantley predicted "this cult of man-sawing office girls" was "destined to find a cult of its own," but the play has not received the attention it deserves, and this is primarily due to the piece's dark humor and Sapphic sensibility, which were literally lost in translation in the move from WOW to NYTW. ${ }^{41}$ NYTW boasts sophisticated, liberal audiences, consisting mostly of conventional, white, middle-class subscribers, viewers who are progressive but not necessarily radical. As if anticipating the undecipherability of lesbian humor, the NYTW program went to great lengths to explain the play to audiences, stressing the fact that the show was a satire and intended to be funny. As Dolan has written, "the pedagogical component of the program note seemed designed to thwart" potentially negative responses, especially from heterosexual men, who might be inclined to storm out of the theatre after just a few scenes. "The program's caveats seemed ... their own form of discrimination." Why, Dolan asks, do we feel "the need to teach people about parody when it was being wielded, finally, by lesbians?"42

Kate Davy attributes the play's mixed reception to the fact that "lesbian desire played out excessively as an oppositional strategy [is] lost outside the context of WOW." ${ }^{43}$ Brother Kron believes this extends beyond the lesbian "problem" to a broader issue concerning the gender disparity of the theatrical canon, noting that the play

examines the ways in which women are the enforcers of sexism. The rules that are enforced involve weight, food, sexuality. Proof that we were covering uncharted territory was in the disconnect between the responses of men (notably male reviewers) and women. Women recognized what we were doing because they had experienced it. Men did not because they had never seen it before . . . the emotional violence between the women did not show up on their radar. They tended to see the play as a revenge fantasy, which it clearly is not. ${ }^{44}$

The NYTW audiences misread the play, just as most people misread or fail to read 
the events on which the play is based, in part because violence between women is occluded by social mechanisms and in part because we want to or have been trained to ignore the roots of female sadism. The Secretaries allows audiences to witness what is normally hidden in a service economy: both the violence between women and how companies play upon this violence in the creation of policies they put into place in order to facilitate the most felicitous performance of affective labor possible.

The Five Lesbian Brothers' The Secretaries is a satire of the commodification of affective labor, one that revels in stereotypes about women and emotions, especially those surrounding menstruation. In Scene One of the play, a large sign hangs in the office that reads "one accident free day." In the penultimate scene, the sign reads "twenty-eight accident free days." The Secretaries spans the length of one lunar month, which is the same as a woman's menstrual cycle. It culminates on kill night and the ritual sacrifice of a lumberjack, which takes place on the evening when the women get their periods. The Secretaries depicts emotional laborers as exploited actors in the theatre of informational capitalism. Despite outward appearances, these ladies are mere functionaries who have banal, dead end jobs, bellicose bosses who make unreasonable demands of them, and massive inferiority complexes. These women are overworked, under appreciated, and actively discouraged from having any type of life outside of the office. This play — which features secretaries played by women acting as workers who can no longer act as if they are feeling what they are feigning - reveals the extent the protagonists go to in order to create believable characters in the drama of affective labor. As Davy has astutely observed, "In The Secretaries it is lesbians who are in drag, playing out the gender marked categories of 'woman' and 'secretary.' Each scene depicts conflict and psychosis as a product of material conditions, rather than personal failure." 45 The point I wish to emphasize is the immaterial conditions of their exploitation, their affective labor.

Emotional labor should seem effortless, according to Hochschild. To show that it takes effort "is to do the job poorly." The more "natural" at her job a secretary seems, "the more the labor does not show as labor."46

The transformation of Patty, a freshly minted graduate of secretarial school into a rage slave for the corporate machine, is accomplished by a rigorous and continual rehearsal of emotion management in which the company makes outrageous and repeated occupational demands on her feelings. I detail here three particularly hilarious examples of the ways in which Patty is indoctrinated into rage slavery in the play: office banter, company sponsored social activities, and kill night. Office banter is a form of emotional labor that helps workers maintain a unified and collective mood and reinforce a corporate identity. The secretaries' banter, which takes the form of both bitch sessions and pep talks, consists almost exclusively of complaints about their bodies. The women discuss shopping, the merits of the SlimFast diet program, and the benefits of various exercise routines. 
On the surface, their chitchat seems banal, but as the play reveals, office banter is a complex and highly codified language that is extremely important in the selfregulation of emotional labor.

Office banter is the way in which occupational structures of feelings, those important but "unofficial" company policies, are conveyed. Patty first becomes aware of the existence and importance of Cooney's unwritten rules when she brings a salad for lunch. The minute Patty puts the Tupperware container on her desk, the secretaries - who don't even take a proper lunch break, but eat while working-hover over the salad and break out into a fit of clicking, the secret secretarial language that Patty, who is both new and only a receptionist, does not speak. Through office banter the secretaries teach the rookie about Cooney's eating taboo, the company "policy" on consuming solid food. As Patty eats, her coworkers sip their shakes, exaggerating the motions and sounds, while quizzing Patty on the number of calories in a cucumber. "We do the SlimFast plan," Ashley tells Patty. "It's healthier than food. . . Y You should try it." A bit slow to catch on, Patty asks the secretaries why they diet, given the fact that they are all so gorgeous, to which Ashley replies, "It's not just for looks, Patty. It is for fitness too." "It's what makes secretaries so strong," adds Dawn. SlimFast shakes are "better than food, really," explains the manager, Susan. "They [SlimFast shakes] were invented by a doctor." 47

Patty's introduction to company policy through office banter is one example of what Hochschild calls "feeling rules," guidelines that govern emotional labor. Feeling rules are a way of describing how "we intervene in feelings in order to shape them." ${ }^{48}$ They are enforced by rule reminders, which are issued regularly as a means of positive reinforcement or when emotional conventions have been broken and need repair. When Peaches is put on notice for being overweight, she asks Patty to help with rule reminders about her diet. "If you see me with a bear claw or a bag of mixed nuts in my hands, just give me a little slap on my face, OK?" Peaches implores to Patty, "Just a little slap so I'll associate it with eating solids, OK?" ${ }^{49}$ Initially Patty refuses to slap Peaches, chiding her coworker for succumbing to misogynist ideals of female beauty, but within no time she's popping Peaches in the mouth over pistachios without even being asked.

Exchanges such as these reveal the depth of the women's self-loathing, and more importantly show the ways in which workers police each other with respect to unofficial company policies. Office banter helps foster an image of the perfect secretary to which no woman can compare, making the workers feel inadequate and thus incredibly lucky to have their jobs. And how the secretaries love their jobs. At least that is what they keep telling themselves, over and over again, as if the repeated telling will make it true. In the play's opening song, the protagonists sing, "we are secretaries like we always dreamed we'd be. We get to wear nice clothes and get paid a salary." 50 
Company sponsored social activities are another way Cooney makes occupational demands on the secretaries' feelings. Cooney hosts a number of unpaid events that take place after hours. Though advertised to the secretaries as perks, these events are really obligations. They intrude upon the private lives of the women and blur the distinction between work and home. The social events make claims on the private lives of the secretaries and are designed to strengthen the bond between workers and thwart the development of entanglements with anyone outside of the mill. Events such as Health and Beauty Night sleepovers at the Hollyhock Hideaway Hotel last the entire weekend. With the secretaries busy engaging in office banter with their coworkers around the clock, there is little time to develop external relationships, especially romantic and familial attachments. The secretaries are actively encouraged to identify with the corporation and its employees and to refrain from any associations that might threaten company loyalty. Lovers and families compete for the secretaries' time and emotional labor and are actively discouraged through Cooney sponsored social activities, the most uproarious example of which is the Big Bone Organization for Women (B.O.W.). ${ }^{51}$ (See Figure 1.)

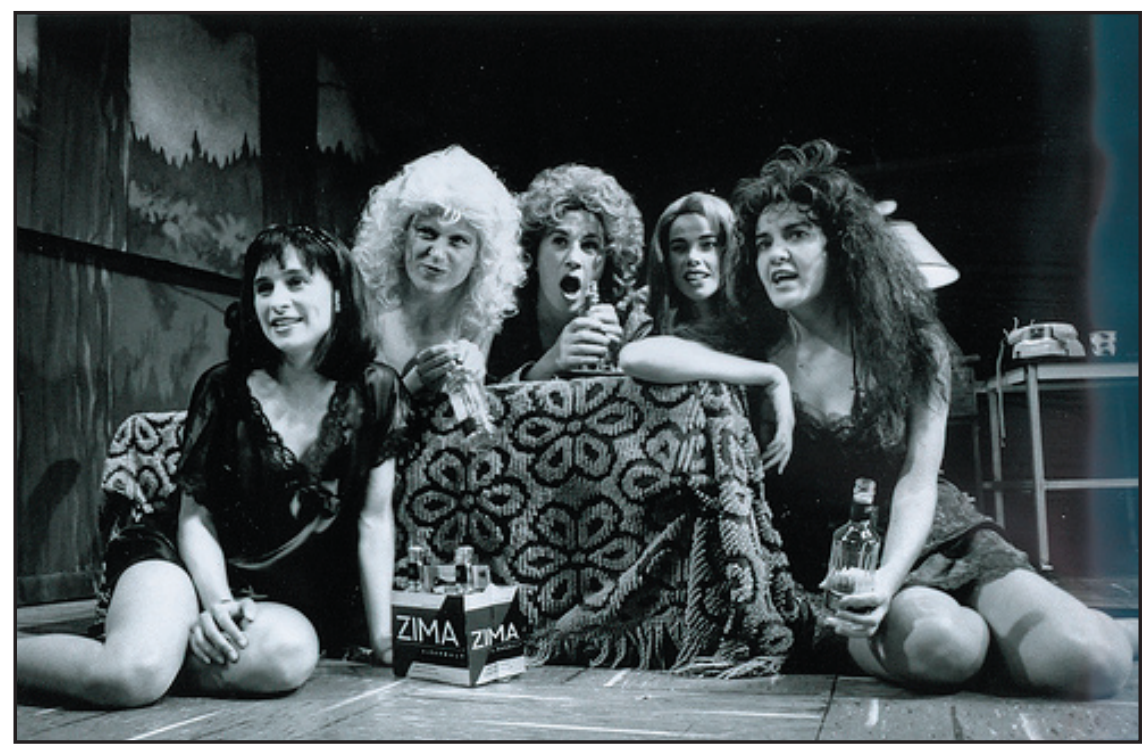

Fig. 1. Occupational demands on feelings: A B.O.W. Health and Beauty Night Sleepover. From left to right: Patty (Dominique Dibbell), Ashley (Babs Davy), Peaches (Lisa Kron), Susan (Peg Healey), and Dawn (Moe Angelos). (C) Joan Marcus).

B.O.W. is a volunteer organization that the secretaries must join if they want to advance their careers and please their boss. The office manager/executive secretary, Susan, is the founder and president of the group, which is curiously only open to employees of Cooney Lumber Mill. Patty is invited to join once she is promoted from receptionist to secretary. Upon her initiation, Susan presents her 
with a membership kit, which includes a "Welcome to B.O.W." video, an organ donor's card, guidelines for dress code and nail length, a button that says "hugs not intercourse," and a copy of the celibacy agreement she must swear to uphold. The meeting begins as usual, with an invocation. "We thank you for the opportunity to meet for shakes and fellowship," the women chant. "Please help us word process without error, to follow the SlimFast diet plan, and to make it through that time of the month together." ${ }^{2}$

After the invocation, Susan takes up the collection, which is not exactly a financial offering. The stage directions read "the girls reach under their skirts, remove their bloody tampons and deposit them in a Ziploc bag provided by Ashley." During this transaction, the women conduct the meeting as if this were completely normal behavior, which sent the audience at WOW into fits of laughter. When the new initiate Patty asks Susan later about the tampon collection, Susan explains matter-of-factly, 'It's research. I'm writing a book about office workers. I have a management theory based on using people's natural body rhythms to facilitate a more cohesive work unit in the office. ${ }^{953}$ Ashley confirms this, adding that she is the one typing the manuscript (a task that surely falls outside of her job description).

Together, the tampon collecting and the celibacy agreement effectively control employees' bodily and affective rhythms. When Susan sees red, she knows that all systems are go. Not only is she sure that her workers aren't pregnant, but she also knows that the women are on the same menstrual cycle, which means that the office is subject to only one week of emotional disturbance, rather than the constant and persistent disruptions that would occur if the secretaries had their periods at different times of the month. It also means the secretaries are in synch for kill night, the planning of which is the real business that takes place at B.O.W. meetings. While celibacy agreements and tampon collecting would be illegal corporate practices if required by Cooney Lumber Mill, they are seen as perks or the small price of membership into an elite circle when facilitated through B.O.W., a volunteer organization the secretaries are, for all intents and purposes, coerced into joining. ${ }^{54}$

Like solid food, heterosexual relationships are taboo at Cooney. Company policies and practices regulate the secretaries' affective labor by promoting a homosocial environment and actively discouraging (read: prohibiting) sexual reproduction. Homoeroticism is not only tolerated but actively encouraged through B.O.W., sleepovers, and company sponsored shopping trips. Susan flirts, teases, and manipulates her employees so that they all fall in love with her and will do anything she asks, from working weekends to committing murder. The queer sociality engendered at the mill is hardly the utopic image of the lesbian nation imagined by separatists in the 1970s, however, and the one thing Susan cannot abide is for the secretaries to fall in love with each other.

When Susan discovers that Dawn had sex with Patty on the vibrating mattress 
at the Hollyhock Hideaway Hotel (before she had the chance to bed Patty first), the scene turns ugly quickly. Susan reprimands Dawn, not by writing her up but by sexually humiliating her. Susan seduces Dawn at work, going down on her in the middle of the office pod after everyone has left for the day. Just when Dawn is about to climax, Susan bites her viciously and pulls away. Wiping the blood from her mouth, Susan snarls, “You don't make a move I don't know about. You don't have a thought I don't already know. . . . Don't fuck with me, Dawn. Don't fuck with my rules. DON'T FUCK PERIOD. End of discussion." As Dawn gathers her stuff and hobbles dejectedly toward the door, Susan tells her, "I hope you know how much I love you. I make these rules for a reason." ${ }^{55}$

The misogyny of the occupational demands on the secretaries' feelings is masked because it is a female supervisor who makes and enforces the rules. The absurd logic parodied here is the idea: "how can it be sexist if it is a woman who is doing it?" The secretaries accept these exploitive intrusions into their private lives because they view their job as a privileged position. Though one might expect, or hope, they would express outrage at the injuries inflicted upon them, they exhibit only fear, fear of losing their coveted jobs. Any anger the secretaries might feel about being so completely exploited by the policies of the mill becomes nefariously and perversely integrated into the capitalist system. Their anger is translated into fear, and fear is translated into an operational requirement, a mandatory tool of the trade. The secretaries are deathly afraid of being fired, but also of losing favor with Susan. They eagerly configure and reconfigure themselves into the sadistic mold of a model mill employee. Their anxiety about being replaced by one of the hundreds of women waiting to take their jobs is channeled into their becoming even more flexible, adaptable, and self-sacrificing. As Patty recounts in her opening monologue, "Only the best secretaries in the world work for Cooney Lumber Mill in Big Bone, Oregon, the world's largest supplier of fine pine. When I graduated, it was the only place I applied. On a million to one shot, I got lucky."

In other words, any woman would kill to be a secretary at Cooney. The joke is, of course, that they do kill to work there. B.O.W., it is revealed, is simply a cover for Susan's cult of castrating clerks. Once a month they ritually slaughter a lumberjack in a ceremonial blood bath the secretaries call kill night. Kill night is an orgiastic free for all, a bloody bacchanal where the secretaries gorge themselves on forbidden food and revel in emotional excess. ${ }^{57}$ (See Figure 2.) The secretaries' periods provide the perfect excuse for their dastardly deeds. During menstruation, women are not only allowed to be emotional, they are expected to be hysterical, irrational, and downright nasty. The women exploit this stereotype, using it to their advantage by murdering men in broad moonlight. Kill night is the only time when the secretaries express feelings they actually have rather than feelings that are dictated by their occupation. That is the illusion anyway, the perfect alibi. As the secretaries' sing on kill night, when it comes to emotional labor, it's "all in the 


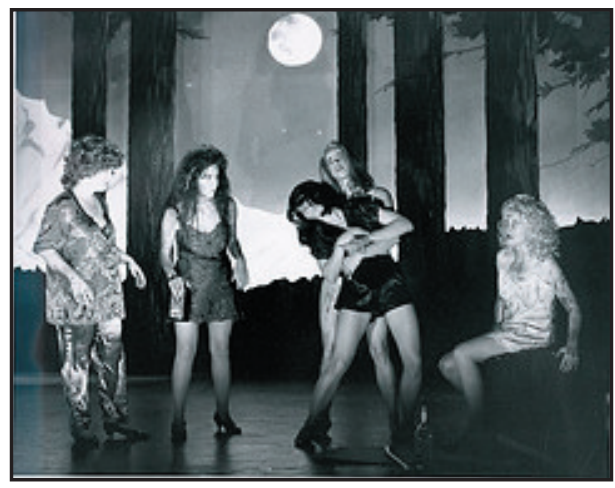

Fig. 2. The orgiastic free for all that is kill night. From left to right: Peaches (Lisa Kron), Dawn (Moe Angelos), [behind] Susan (Peg Healey), Patty (Dominique Dibbell), and Ashley (Babs Davy). (C Joan Marcus).

execution." 58

As is typical of most carnivalesque rites, the events of kill night ultimately reinforce the status quo, though in this case they also effect a curious queering of the normative order and its concomitant structure of feelings. Kill night does not represent the return of the secretaries' repressed rage so much as it marks their transformation into rage slaves, signaling that they have become fully indoctrinated emotional laborers in the service economy. While it may seem as if these murderous maenads are acting — and acting out — of their own volition, they are actually playing their parts in a much more diabolical and skillfully scripted plot. The play itself provides ample evidence that the mill, not the secretaries, profits from the covert activities that take place on kill night. As Brother Kron noted earlier, the play is not a revenge fantasy, and the lumberjacks are nice guys who "don't deserve to die."

Kill night is not a marker of the secretaries' agential self-empowerment; rather, it is the result of their emotional dissonance, affective labor's correlative to the production worker's alienation. Emotional dissonance occurs, according to Hochschild, when an emotional laborer can no longer tell the difference between feeling and feigning, being and acting. As a result of the commodification of affect, workers eventually become so alienated from their emotions, drives, and desires that they cannot distinguish right from wrong, vengeance from justice. Rather than taking their employer to task for its exploitive practices, the secretaries fault themselves. Unable to feel appropriately, the women still somehow manage to feel guilty. As Susan explains to Patty, "we don't kill [the lumberjacks] because they're bad. We kill them because we're bad."

Bad is multivalent, and the range of meanings shows the Brothers' collective comic genius. Bad is how the secretaries judge themselves for failing to reconcile feeling and feigning. In terms of the logic of the performance, bad is criminal, which the secretaries clearly are. They torture and murder innocent men for sport. This play is a satire, so bad is also good. The secretaries, like The Five Lesbian Brothers, are bad asses who cause all manner of gender trouble. They subvert sexual stereotypes and instill fear in the hearts of men. The play encourages audiences to celebrate their delinquency and their radical departure from traditional female decorum. But it also implores us to re-examine what we think of as transgressive 
behavior. If Susan, the secretaries, or audiences believe they are liberated, even temporarily, on kill night, then they are suffering from false consciousness.

To conclude that the secretaries are simply victims of the capitalist machine or "The Man" would be to misinterpret the play and The Five Lesbian Brothers' pointed critique of mainstream feminism. Susan offers two reasons for the secretaries' violence, both of which are absolutely ridiculous and intended to satirize the cult of victimization that has plagued feminism for far too long. The first justification she gives is the abuse excuse, which is the colloquial term for the battered woman's defense. In a conversation with Patty about how she became a killer, Susan explains, "My story goes like this. I was born and then I was fucked over and fucked over and fucked over so many times that I can't separate it out anymore." ${ }^{61}$ Unable to take the abuse any longer, Susan would have us believe, she simply snaps and begins to fight back. This justification might have merit if she were acting in self-defense or if the crimes were committed against those who actually aggressed her, but they are premeditated acts against innocent victims.

The second rationalization Susan offers is retribution. Haven't you noticed, Susan asks Patty, “how men's clothes are better made than women's and usually half as expensive. It's a crime. A while ago, before you came on we decided to rectify this crime. We decided we wanted good jackets, too," Susan explains. "It gets cold in winter. Only the lumberjacks won't give us their jackets, so we take them." 62 The crime of murder, Susan would like Patty to believe, is justified because the original crime, the lumberjack's entitlement to warm coats and comfortable boots, goes unnoticed and unpunished while the women have to suffer Big Bone winters in fashionable secretarial attire: heels, hose, and skirts; uniforms that are uncomfortable and inadequate. If this were true, why would Susan orchestrate the slaughter of lumberjacks? Why target only blue collar workers? Why not murder men in management, who also enjoy warm coats and boots, and in styles that are certainly more fashionable for the designer-conscious clerks?

The irony of kill night is that the secretaries are bad and their bad behavior is very good for business. Cooney sanctions - we might go so far as to say underwrites - the slaughter of the lumberjacks because its continued economic success depends upon it. The fact that the company neither investigates the accidents nor enacts stricter measures to safeguard their workers (just think of the insurance premiums and compensation packages to victims' families they would save if they did) indicates the company's complicity in the events. Despite the incredibly high fatality rate of men at the mill, the startling coincidence that the accidents occur every twenty-eight days, and the fact that the secretaries are stark raving mad and eating everything in sight (including copy toner) on the day of each incident, no one suspects these miscreants of murder. Mill management isn't clueless; it is calculating.

Cooney profits from kill night — we shall see exactly how in just a moment- 
and they do so without fear of getting caught because it is head secretary Susan who executes, quite literally, the order. Susan's oppressive management style, and in particular her taboos around food and sex, strengthen the secretaries' loyalty to the extent that they kill for her. Susan creates the celibacy agreement and strictly enforces the SlimFast diet plan with the aim of fostering animosity and ill will among the ranks to make the women angrier and more violent. The driving force behind these practices is to ensure that the secretaries are horny and hungry on the twenty-eighth day of every month. Susan makes sure the secretaries never have access to the big boss, Mr. Kembunkscher. In fact, the only indication we have that the man actually exists is a voice on the intercom. His hands are not only clean but invisible. When Susan tells Peaches that Mr. Kembunkscher has put her on notice for being overweight, even Peaches doubts the veracity of this message. Maybe he gave the order, fusses Peaches, "Maybe he did. Susan said he did. She said Mr. Kenbunkscher isn't happy with me. He isn't happy with my performance. . . . She said he said I'm not the right size." Peaches is the weakest link in the office chain, and the other secretaries refer to her as "a charity case" because they routinely have to help her with her work. Susan only keeps Peaches around because she is, the audience learns, the most enthusiastic executioner, the celebrated "star of kill

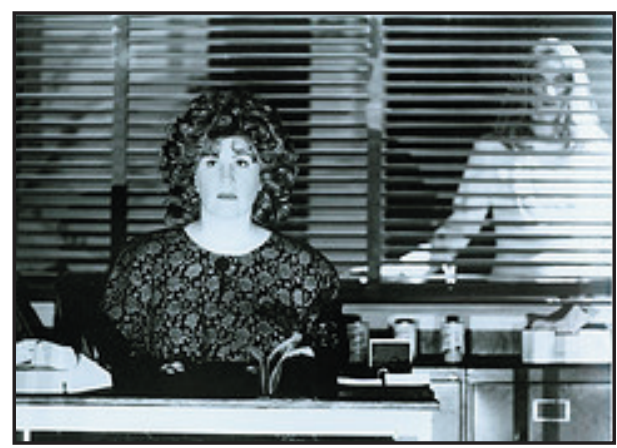

Fig. 3. Executive privilege. Susan (Peg Healey) keeps a close watch on her star of kill night, Peaches (Lisa Kron). (C Joan Marcus). night."

But what could the mill possibly gain by having its administrative staff kill off its labor force? The play makes clear that the lumberjacks' deaths seem accidental, so kill night is not a corporate strong-arm tactic designed to instill fear in the men or make them submissive to authority. Kill night is Cooney's way of managing surplus labor. These seasonal workers aren't laid off during spring rains or when supply and demand falters (which would mean expensive unemployment claims); they are laid to rest. The lumberjacks are given the slip all right, but it's red not pink. As far as Cooney is concerned, lumberjacks are a dime a dozen, and as crew leader Buzz himself notes, the mill has an endless supply of laborers from the prison and halfway houses in town. Good secretaries, on the other hand, are worth their weight in gold. They are even more valuable when, like Patty, they don't know their own worth.

Not every lumberjack is grist for the mill. The hapless hulks selected for slaughter are those who have made the mistake of falling in love with a secretary. Buzz, who is being groomed by none other than Mr. Kembunkscher, is killed 
because he woos Patty and because he commits the grave error of thinking that he is possibly more important to her than her job at Cooney Lumber Mill. Buzz seals his fate during a phone conversation with Patty. When she tells him she has to get off the phone and back to work, Buzz snaps at her. "Christ, Patty, it's just a job." To which Patty replies, "No, it's not. It's more than a job. But you wouldn't understand that." ${ }^{94}$ Being a secretary is a girl thing, and as a guy, Buzz just doesn't get it - that is, until the end, when Buzz meets saw. For lumberjacks who fall in love with secretaries at the Cooney Lumber Mill, the first cut is not only the deepest; it is fatal. The reason is simple. If the love between lumberjack and secretary were permitted, the couple might marry and have children. The secretary would have competition for her attention and conflicting demands on her emotional labor. Her identity as secretary would be in jeopardy, as there is no way a woman can perform multiple believable characters simultaneously.

Cooney relies upon its rage slaves to abolish the surplus labor of lumberjacks and annihilate the means of (re)production that jeopardizes its affective labor force. In an interesting inversion of socio-economic theory, heteronormative sexuality threatens rather than ensures the productivity and profitability of the capitalist enterprise. The rage slave, not the nuclear family, fuels economic postmodernization. The play suggests that we need to revise Engels's The Origin of the Family, Private Property and the State as the rules of the game have most certainly changed. ${ }^{65}$ The ideal rage slave, at least as far as Cooney is concerned, is the lesbian. Not just any lesbian, but an angry lesbian.

\section{Bittersweet Queer Sociality}

I have offered here a reading of The Secretaries as a satire of the commodification of human feelings in an age of affective reproducibility. Affective labor, like domestic labor, is work that never stops. Just as there are no time clocks to punch for wives and mothers (not to mention nannies, maids, and slaves) that mark the end of a day of domestic drudgery, there is no actual start time or stop time for the secretaries' shift at Cooney Lumber Mill. These women may get paid for toiling nine to five, but they never actually quit working. Office retreats, corporate lunches, and working vacations are just some of the ways businesses blur the line between company time and personal time. This extends beyond the level of the worker to the level of the social. In economic postmodernization, more and more businesses are open 24/7, 365 days per year. The Monday through Friday workweek is quickly becoming a thing of the past, as is the division between the office and home, work and leisure. "Benefits" such as flex-time and telecommuting further obscure these divides.

In a service economy based upon the buying and selling of emotional labor, the commodification of affect is inevitable. I have termed a laborer who experiences emotional dissonance as a result of this process of commodification a rage slave. 
This provocative parody by The Five Lesbian Brothers exposes what is occluded by the mechanisms of informational capitalism, namely its dependency upon rage slave labor, the paradigmatic example of which is the angry lesbian. As the policies of Cooney Lumber Mill-from the celibacy pledge to the culling of lumberjacks - makes clear, the very forces that made industrialization possible, namely the nuclear family and heterosexual reproduction, are precisely those social structures that pose the greatest risk to informational capitalism's emotional labor force. In the play, secretaries are transformed into lesbians (a.k.a. nonreproductive women) and rage slaves simultaneously.

One unexpected and unintended consequence of economic postmodernization is the waning of the heterosexual imperative and a queering of the social order. The play celebrates this new rainbow economy that detaches capitalism from heteronormativity while at the same time serving as a pointed critique of the commodification of queer. The Five Lesbian Brothers underscore the fact that this loosening of the heterosexual imperative is far from liberating. First, it has been supplanted by homosocial and homonormative dictates that are far more restrictive, coercive, alienating, and violent. Second, it replicates and exacerbates existing gender, class, and racial disparities. Women fare no better as emotional laborers in a market economy than they do in a domestic economy, and some might argue worse. Third, it co-opts what bell hooks calls our "killing rage," ${ }^{\prime 66}$ the militant anger that fuels activism and social change. Without it, there would have been no Civil Rights Movement, no Women's Liberation Movement, no ACT-UP. The anger that energized and sustained the Black Panthers, the Furies, and Queer Nation is no longer a viable strategy of political resistance.

The killing rage the secretaries feel in response to their economic exploitation is understandable, but their killing sprees fail as an act of transgression because their rage has been commodified by their employer and used to support the very structures the protagonists seek to subvert. In an age of affective reproducibility, rage - far from being a disruptive or potentially emancipatory emotion that disturbs power dynamics and challenges institutional hierarchies - is actually the affective fuel on which the perpetuation of informational capitalism depends, thus rendering resistance and revolution nigh impossible. While The Secretaries revels in the fact that affective labor produces a queer sociality and queer collective subjectivities, it also betrays the profound ambivalence lesbians, as rage slaves par excellence, have to this queer new world.

In conclusion, I would like to explore this ambivalence in greater detail, beyond the realm of the secretarial pool to another bastion of affective labor, the world of the theatre. The Five Lesbian Brothers are the most commercially successful lesbian theatre artists to emerge from WOW. While the founding generation of performers positioned themselves in opposition to the mainstream, the Brothers actively courted it. The Brothers' $t$-shirts and letterhead brag that the group is "commercially 
viable yet enchantingly homosexual." Their commercial aspirations are imaginable because they are the beneficiaries of the emotional labor of older lesbian performers such as Peggy Shaw, Lois Weaver, Carmelita Tropicana, and Holly Hughes, and because the formation of their collective just happened to coincide with the rise of queer theory and activism. Queer became cool in the 1990s in a way that lesbian has never been (except perhaps in isolated cases such as Ellen DeGeneres and $L$ Word). Brother Kron acknowledges this fact when she states: "My solo work and the work of the Brothers received professional recognition beyond what had been available to lesbians who came even a few years before us" because "[w]e were in the right place . . . at the very moment when some mainstream theatres were opening their doors to lesbian work." ${ }^{67}$

Depending upon whom you ask, that opening seems more like a crack that a handful of crafty and resourceful dykes managed to squeeze through before the door was closed again. If any lesbian troupe had a chance at commercial success, artists and critics believed, it was The Five Lesbian Brothers. Five of their six shows have been produced off-Broadway, and Brother Kron's Well was the only new work by a female playwright (gay or straight) to debut on Broadway in 2006. But neither Kron nor the Brothers collectively can say they have experienced the sweet smell of success. "That the Brothers have not managed to sustain commercial success has nothing to do with their skill as performers or the ingeniousness of their scripts," according to Davy; "it has to do with the limitations under which women in general labor in theatre, combined with the magnitude of their threat-acute unease is a not uncommon effect of their productions. ${ }^{~}{ }^{68}$ In other words, these lesbians make audiences feel funny instead of good.

With the exception of a few key figures, most notably playwright Paula Vogel and actress Cherry Jones, lesbians have enjoyed precious little fame or financial reward as a result of the queering of contemporary American theatre, and certainly nothing that can compare with their gay male counterparts Tony Kushner, Terence McNally, Jonathan Larson, Doug Wright, and Larry Kramer, to name only a few. "I could write a long and bitter book full of offers we would have had," laments Kron, "if we were not lesbians." ${ }^{\circ 9}$ Being a minor celebrity who still has to work temporary jobs (read: secretary!) to make ends meet when you have talent and you might/would/could be more successful were you not a lesbian is indeed a bitter pill to swallow. But why a "bitter book"? Why not unleash a tirade or pen an angry manifesto? Is bitter what's left when our killing rage turns to resentment, when our ire has been commodified and co-opted? Is a bitter dyke what becomes of an angry lesbian, of a rage slave in an age of affective reproducibility? Is a book more definitive than a play; does it signal closing a chapter, as in the bitter end of radical lesbian theatre and activism?

While Kron could write a bitter book about a career that could have been, she probably will not because, she adds, "mostly I feel grateful." ${ }^{\prime 70}$ Disappointed but not 
disenchanted or deterred, Kron and The Brothers are ambivalent yet persistent. It's not that the queering of the social order effected by the predominance of emotional labor does not bear fruit for lesbians in the theatre, for it does in the form of places like WOW, creative and nurturing spaces of improvisation engaged in utopian projects of world-making, and in spaces like NYTW where The Brothers have achieved a modicum of commercial success. It's that the fruit is bittersweet.

\section{Notes}

${ }^{1}$ I would like to thank Jill Dolan, Kate Davy, Natasha Hurley, Sabine Haenni, Dagmawi Woubshet, Iris Smith Fischer, Jocelyn L. Buckner, and the anonymous JDTC reviewers for their affective labor and thoughtful comments on various drafts of this article.

${ }^{2}$ Peggy Phelan, "The Serious Comedy of Hope: Introducing the Five Lesbian Brothers," The Five Lesbian Brothers: Four Plays (New York: Theatre Communications Group, 2000) xv.

${ }^{3} \mathrm{xv}$.

${ }^{4}$ bell hooks, "Moving Into and Beyond Feminism." Outlaw Culture: Resisting Representations (New York: Routledge, 1994) 211.

${ }^{5}$ Arlie Hochschild, The Managed Heart: Commercialization of Human Feeling (Berkeley: U of California P, 1983).

${ }^{6}$ See Karl Marx, Wage-labor and Capital (New York: New York Labor News Company, 1902).

${ }^{7}$ Lauren Berlant's conception of "post-fordist affect" provides another way to think about the secretaries' emotional labor. See Lauren Berlant, "Nearly Utopian, Nearly Normal: Post-Fordist Affect in La Promesse and Rosetta," Public Culture 19. 2 (2007): 272-301.

${ }^{8}$ Raymond Williams. "Structures of Feeling." Marxism and Literature (Oxford: Oxford U P, 1977) $128-35$.

${ }^{9}$ Economic postmodernization is also coeval with the development of the pill, an escalation in divorce rates, Roe v. Wade, Title IX, and an increase in the number of women attending college. Films depicting this transition and the anxiety this shift has engendered in American society soon followed, including many that featured feminist and proto-feminist clerical workers. The Secretaries pays homage to the paradigmatic example of this genre, the 1980s cult classic 9 to 5 , starring Dolly Parton, Jane Fonda, and Lily Tomlin. Fonda was, and is, an outspoken feminist. Tomlin was a closeted lesbian at this time, but her sexuality was an open secret in the community, and Parton is rumored to have been involved in an on-again, off-again relationship with her manager. These facts are parodied in the dynamics of the Big Bone secretarial pool. 9 to 5 spawned a popular sitcom featuring Parton's younger sister Rachel in her role, Valerie Curtain in the Fonda part, and Rita Moreno as Tomlin's character. It aired on ABC from 1982 to 1983 and again from 1986 to 1988, with Sally Struthers replacing Moreno. The film Working Girl (1988) with Melanie Griffith, Sigourney Weaver, and Harrison Ford, which was nominated for six Oscars, is clearly also a reference point for the Brothers' play.

${ }^{10}$ Michael Hardt, "Afffective Labor," Boundary 2, 26.2. (1999): 90, 96.

${ }^{11} 89$.

${ }^{12}$ Patricia Ticineto Clough, ed. The Affective Turn: Theorizing the Social (Durham: Duke UP, 2007).

${ }^{13}$ Many businesses have found it both difficult and expensive to comply with the Patriot Act, which requires reporting financial records as well as detailed usage statistics. Businesses are worried not only about checks and balances that protect access to these records, which can contain trade secrets, but what federal agents might discover in terms of unrelated crimes that could lead to governmental investigations and penalties. There is also the threat of lawsuits by individuals claiming breaches of civil liberties. In 2005, three of the nation's most powerful lobbying outfits, the U.S. Chamber of Commerce, which represents three million businesses, the National Association of Manufacturers, and the National Association of Realtors, joined the ACLU and librarians in a law suit to reform the Patriot Act. See "Business Organizations Back Senate Patriot Act Reforms Protecting Consumer Privacy." American Civil Liberties Union 5 August $2008<$ http://www.aclu.org/safefree/general/19944prs20051005.html>.

${ }^{14}$ Multitude: War and Democracy in the Age of Empire (New York: Penguin, 2004) 108. Here Hardt and Negri consider affective labor to be just one of the many types of "biopolitical production," labor that creates social life itself. Biopolitical production and political organization are the two primary characteristics of "multitude". The concept of multitude involves the desire for a postgendered and 
postracialized world, a world in which such realities do not determine hierarchies of power. For more on the affect/emotion distinction, see Fredric Jameson, Postmodernism or, The Cultural Logic of Late Capitalism (Durham: Duke U P, 1991); Rei Terada, Feeling in Theory: Emotion after the 'Death' of the Subject (Cambridge: Harvard U P, 2001); and Brian Massumi, Parables for the Virtual: Movement, Affect, Sensation (Durham: Duke U P, 2002).

${ }^{15}$ See Sara Ahmed, The Cultural Politics of Emotion (New York: Routledge, 2004); Ann Cvetkovich, An Archive of Feelings: Trauma, Sexuality, and Lesbian Public Cultures (Durham: Duke U P, 2003); and Sianne Ngai, Ugly Feelings (Cambridge: Harvard U P, 2005), to name only a few.

${ }^{16}$ These statistics represent the most current data by the U.S. Department of Labor. See Women's Bureau, U.S. Department of Labor, "20 Leading Occupations of Employed Women, Full-time Wage and Salary Workers, 2003 Annual Averages." 5 June 2008. <http://www.dol.gov/wb/factsheets/20lead2003. htm $>$. The teaching statistic represents elementary and middle-school teachers. The number for kindergarten teachers is even higher, $98.3 \%$ female.

${ }^{17}$ These statistics reflect the time period in which The Secretaries was produced. See Daphne Spain, “The Contemporary Workplace." Gendered Spaces (Durham: U of North Carolina P, 1992) 118-20.

${ }^{18}$ Gayatri Chakravorty Spivak, "Scattered Speculations on the Question of Value." In Other Worlds: Essays in Cultural Politics (New York: Routledge, 1988) 167.

${ }^{19}$ Virginia Woolf, A Room of One's Own (New York: Harvest Books, 1929) 37.

${ }^{20}$ vii.

${ }^{21}$ Some radical feminist Marxists, like the brilliantly deranged Valerie Solanas, believed that all work was oppressive and the entire capitalist system should be overthrown. See Valerie Solanas, The SCUM Manifesto (New York: Olympia P, 1969).

${ }^{22}$ hooks 230.

${ }^{23}$ John Stuart Mill, The Subjection of Women (New York: The Constitution Society) (10 June 07. $<\mathrm{http}$ ://www.constitution.org/jsm/women.htm $>$ ). All quotations from Mill are from this source.

${ }^{24}$ Mill's nervous breakdown, or breakthrough, led him to discover the realm of feelings and emotions and prompted him to turn away from Bethamite utilitarianism towards a more Romantic view of the world. For more information, see Chapter Five of John Stuart Mill, The Autobiography of John Stuart Mill (New York: Columbia U P, 1960).

${ }^{25}$ Weber considered affectual actions to be one of the four types of social actions, along with value-rational (action which leads to a goal and which is pursued after considering its consequences and means), instrumental (action which leads to a goal but that does not consider the consequences or means), and traditional actions (an action undertaken because it was done in the past). Affectional actions are irrational emotional responses to a situation and express one's personal feelings. They can take the form of uncontrollable reactions (such as crying at a funeral or cheering at a sporting match) or tension, which results when a person feels powerless to achieve or obtain something. Weber believed affectual actions result in unproductive workers, but, as both Hochschild and The Secretaries show, affectual actions, perhaps more than any other form of social action, define both laborers and consumers in the current capitalist system. See Max Weber, Economy and Society: An Outline of Interpretive Sociology. Eds. Guenther Roth and Clauss Wittich (Los Angeles: U of California P, 1978): 3-62.

${ }^{26}$ Hochschild, The Managed Heart 5. For a reading of Marx's Capital as a sensational narrative of the workers' body in pain, see Ann Cvetkovich, Mixed Feelings: Feminism, Mass Culture and Victorian Sensationalism (New Brunswick: Rutgers U P, 1992).

${ }^{27}$ Hochschild does not distinguish between the Stanislavski System and Method Acting, and she uses the terms interchangeably. Surface acting is similar to Erwin Goffman's concept of impression management, the effort and energy exerted by a social actor to present a positive impression and to avoid embarrassment. Goffman, Hochschild's mentor, also used theatre to explicate social theory. See Erving Goffman, The Presentation of Self in Everyday Life (New York: Anchor, 1959).

${ }^{28}$ Konstantin Stanislavski, An Actor Prepares, tr. Elizabeth Reynolds Hapgood (New York: Theatre Arts Books, 1948) 148.

${ }^{29}$ Hochschild understands Stanislavski to say that, while imagination is a force that can be influenced and manipulated, feelings are immune from this danger. She cites as evidence from the Hapgood translation: "You can borrow clothing, a watch, things of all sorts, but you cannot take feelings away from another person. My feelings are inalienably mine, and yours belong to you in the same way" (166). She reads Stanislavski as arguing that feelings (those expressions of our private inner-selves) cannot be socially constructed, coerced, or co-opted in any way. According to Hochschild, this is not only possible, it is pervasive in a service economy. The Brothers, like most WOW performers (Deb Margolin of Split Britches being the noteworthy exception), eschew realism and method acting in favor of a more Brechtian style. A new translation of Stanislavski calls into question certain aspects of Hochschild's interpretation and promises to reignite debates about the efficacy of realism for feminist 
performance. See Konstantin Stanislavski, An Actor's Work: A Student's Diary, tr. Jean Benedetti (New York: Routledge, 2008). See also Elin Diamond, Unmaking Mimesis: Essays on Feminism and Theatre (New York: Routledge, 1997); Peta Tait, Performing Emotions: Gender, Bodies, Spaces in Chekhov's Drama and Stanislavski's Theatre (Aldershot: Ashgate 2002); Rhonda Blair, "Reconsidering Stanislavsky: Feeling, Feminism, and the Actor." Theatre Topics 12.2 (2002): 177-90; and Sharon Marie Carnicke, Stanislavski in Focus (New York: Routledge, 1998).

${ }^{30}$ WOW, which began as an international feminist theatre festival in 1980 and soon grew into a collective with a permanent home in New York City on the Bowery's theatre row, has produced some of the most innovative feminist theatre practitioners in the country. Originally located at 330 East 11 th Street from 1982 to 1984, WOW is now housed at 59-61 East 4th Street. See Sue-Ellen Case, Split Britches: Lesbian Practice/Feminist Performance (New York: Routledge, 1996); Kate Davy, "Fe/Male Impersonation: The Discourse of Camp," The Politics and Poetics of Camp, ed. Moe Meyer (New York: Routledge, 1994), 130-48; Alisa Solomon, "The WOW Café," A Sourcebook on Feminist Theatre and Performance, ed. Carol Martin (New York: Routledge, 1996), 42-53. What distinguishes the Brothers, who represent the second generation of WOW performers, from founding members such as Split Britches, Carmelita Tropicana, and Holly Hughes, according to Liz Kotz, is that as products of "a more cynical age," they "take the notoriously campy WOW aesthetic and push it toward its dark underside," producing "a troubled fascination with the imagined decadence and pathology of pre-Stonewall gay culture." See Liz Kotz, "Five Lesbian Brothers: The Fraternal Feminine," Art Forum 01 December 1993. 19 September 2007. <http://findarticles.com/p/articles/mi_m0268/is_n4_v32/ai_14890773>. The Brothers also cite Ethyl Eichelberger, Charles Ludlam, and Karen Finley as influences.

${ }^{31}$ Phelan, "The Serious Comedy of Hope" xiii.

${ }^{32}$ Jill Dolan, "The Feminist Spectator: The Return of the Five Lesbian Brothers.” (26 August 2005. $<$ http://feministspectator.blogspot.com/2005/08/return-of-five-lesbian-brothers.html>.)

${ }^{33}$ This quote is from the playbill of The Secretaries and is featured in both the W.O.W. Café and The New York Theatre Workshop notes.

${ }^{34}$ The Five Lesbian Brothers, The Five Lesbian Brothers: Four Plays (New York: TCG, 2000) 3.

${ }^{35}$ This quote is taken from Lisa Kron's website. 5 July 2008. <http://www.lisakron.com/ bravesmiles.html>.

62.

${ }^{36}$ Alisa Solomon, "Five Lesbian Brothers: No Whining!" American Theatre (September 1998):

${ }^{37} 62$.

${ }^{38} 1990$ is the year Queer Nation was formed in New York City and the year Teresa de Lauretis coined the term queer theory at a conference on gay and lesbian sexualities at the University of California Santa Cruz. The Five Lesbian Brothers actually formed in 1989, a few months before they staged their first show.

${ }^{39}$ Dolan, "The Feminist Spectator: The Return of the Five Lesbian Brothers."

${ }^{40}$ While Brave Smiles . . Another Lesbian Tragedy, the Brothers' second play, also played NYTW in 1993, it ran for only ten shows, as filler between previously scheduled productions. The Secretaries was in very good company at NYTW in 1994, sharing the season that included Tony Kushner's Slavs!, Jonathan Larson's Rent, and Tallahassee by Mac Wellman and Len Jenkin, along with staged readings of new plays, including Doug Wright's Quills and Adrienne Kennedy and Adam Kennedy's Sleep Deprivation Chamber. NYTW also staged Brides of the Moon (1997) and the group's most recent venture, Oedipus at Palm Springs (2005).

${ }^{41}$ Ben Brantley, “A Secretarial Pool Out for Blood,” New York Times 22 September 1994. < http:// theatre2.nytimes.com/>. On Lisa Kron's website, she calls NYTW, not WOW, the Brothers' "theatrical home". 05 July $2008<$ http://www.lisakron.com>.

${ }^{42}$ Dolan, "The Feminist Spectator: The Return of the Five Lesbian Brothers."

${ }^{43}$ Kate Davy, email to the author. 12 December 2007.

${ }^{44}$ The Five Lesbian Brothers, The Secretaries 119.

${ }^{45}$ Kate Davy, email to the author. 12 December 2007.

${ }^{46}$ Hochschild, The Managed Heart 8, 169.

${ }^{47}$ The Five Lesbian Brothers, The Secretaries 133-4.

${ }^{48}$ Hochschild, The Managed Heart 57.

${ }^{49}$ The Five Lesbian Brothers, The Secretaries 151.

${ }^{50} 125$.

${ }^{51}$ The name of the town, Big Bone, is rife with sexual innuendo, while B.O.W. satirizes NOW, The National Organization for Women, a liberal feminist organization, and Susan Curtis is a caricature of its founder and first president, Betty Friedan. The Five Lesbian Brothers are radical lesbian feminists, and 
they parody both liberal and cultural feminism in this play. Friedan's homophobia is well documented in Alice Echols, Daring to Be Bad: Radical Feminism in America, 1967-1975 (Minneapolis: U of Minnesota P, 1989).

${ }_{52}^{52}$ The Five Lesbian Brothers, The Secretaries 149, 146.

${ }^{53} 147,156$.

${ }^{54}$ It is worth noting that in many places it is legal for companies to require samples of menstrual blood from women workers as proof that they are not pregnant. This is routine, for example, in the maquiladoras, factories just over the Mexican border. Corporations claim that such standards are necessary to protect unborn fetuses from possible harm from chemicals and cancer-causing agents used in productions. For more information, see "Where The Borders Of Class, Race, Age And Sexuality Meet," $<$ http://www.womenontheborder.org $>$ and "The Clean Clothes Campaign: Improving Working Conditions in the Global Garment Industry," <http://www.cleanclothes.org/index.htm>.

${ }_{55}^{55}$ The Five Lesbian Brothers, The Secretaries 170.

${ }^{56} 129$.

${ }^{57}$ The stage directions read "the office walls give way to reveal a ritual clearing in a towering wood, illuminated by the light of the full moon" (183). Kill night is meant to parody lovingly the kind of ritualistic, gyno-utopic practice associated with cultural feminism and which one can still find today at the Michigan Women's Music Festival. A similar satirical scene appears in the second half of Caryl Churchill's Cloud Nine.

${ }^{58}$ The Five Lesbian Brothers, The Secretaries 190.

${ }^{59} 119$.

${ }^{60} 180$.

${ }^{61} 183$.

${ }_{62} 179$, emphasis mine.

${ }^{63} 151,131$.

${ }^{64} 160$.

${ }^{65}$ Friedrich Engels, Origin of the Family, Private Property and the State (New York: Pathfinder P, 1972). The play, I argue, suggests that monogamy (be it hetero or homosexual) is no longer the most efficacious form of sexual arrangement because reproduction and production are no longer imbricated.

${ }^{66}$ bell hooks, Killing Rage: Ending Racism (New York: Holt, 1996).

${ }^{67}$ Lisa Kron, "A Straight Line." Cast Out: Queer Lives in Theatre, ed. Robin Bernstein (Ann Arbor: U of Michigan P, 2006) 55.

${ }^{68}$ Kate Davy, email to the author. 12 December 2007.

${ }^{69}$ Kron, "A Straight Line" 55.

7055. 
